\title{
Additive effects of the herbicide glyphosate and elevated temperature on the branched coral Acropora formosa in Nha Trang, Vietnam
}

\author{
C. Amid ${ }^{1} \cdot$ M. Olstedt ${ }^{1} \cdot$ J. S. Gunnarsson ${ }^{1} \cdot$ H. Le $\operatorname{Lan}^{2} \cdot$ H. Tran Thi Minh ${ }^{2}$ • \\ P. J. Van den Brink ${ }^{3,4} \cdot$ M. Hellström ${ }^{1}$ - M. Tedengren ${ }^{1}$
}

Received: 9 May 2016 / Accepted: 21 December 2016/Published online: 22 January 2017

(C) The Author(s) 2017. This article is published with open access at Springerlink.com

\begin{abstract}
The combined effects of the herbicide glyphosate and elevated temperature were studied on the tropical staghorn coral Acropora formosa, in Nha Trang bay, Vietnam. The corals were collected from two different reefs, one close to a polluted fish farm and one in a marine-protected area (MPA). In the laboratory, branches of the corals were exposed to the herbicide glyphosate at ambient $\left(28^{\circ} \mathrm{C}\right)$ and at $3{ }^{\circ} \mathrm{C}$ elevated water temperatures $\left(31^{\circ} \mathrm{C}\right)$. Effects of herbicide and elevated temperature were studied on coral bleaching using photography and digital image analysis (new colorimetric method developed here based on grayscale), chlorophyll a analysis, and symbiotic dinoflagellate (Symbiodinium, referred to as zooxanthellae) counts. All corals from the MPA started to bleach in the laboratory before they were exposed to the treatments, indicating that they were very sensitive, as opposed to the corals collected from the more polluted site, which were more tolerant and showed no bleaching response to temperature increase or herbicide alone. However, the combined exposure to the stressors resulted in significant loss of color, proportional to loss in chlorophyll $a$ and zooxanthellae. The difference in sensitivity of the corals collected from the polluted site versus
\end{abstract}

Responsible editor: Philippe Garrigues

M. Tedengren

michael.tedengren@su.se

1 Department of Ecology, Environment and Plant Sciences (DEEP), Stockholm University, 10691 Stockholm, Sweden

2 Institute of Oceanography (IO), Nha Trang, Vietnam

3 Department of Aquatic Ecology and Water Quality Management, Wageningen University, P.O. Box 47, 6700

AA Wageningen, The Netherlands

4 Alterra, Wageningen University and Research Centre, P.O. Box 47, 6700 AA Wageningen, The Netherlands the MPA site could be explained by different symbiont types: the resilient type $\mathrm{C} 3 \mathrm{u}$ and the stress-sensitive types $\mathrm{C} 21$ and $\mathrm{C} 23$, respectively. The additive effect of elevated temperatures and herbicides adds further weight to the notion that the bleaching of coral reefs is accelerated in the presence of multiple stressors. These results suggest that the corals in Nha Trang bay have adapted to the ongoing pollution to become more tolerant to anthropogenic stressors, and that multiple stressors hamper this resilience. The loss of color and decrease of chlorophyll $a$ suggest that bleaching is related to concentration of chloro-pigments. The colorimetric method could be further fine-tuned and used as a precise, non-intrusive tool for monitoring coral bleaching in situ.

Keywords Coral bleaching $\cdot$ Climate change $\cdot$ Global warming · Pesticides · Digital image analysis $\cdot$ Chlorophyll . Zooxanthellae $\cdot$ Genotype $\cdot$ Tolerance $\cdot$ Adaptation

\section{Introduction}

Coral reefs are subject to increasing anthropogenic pressures, which has led to a circum-tropical decline of reef communities (Wilkinson, 2008). Declines are caused by overfishing (Pandolfi et al. 2003), pollution (e.g., Cervino et al. 2003, Fabricius 2005, D'Angelo and Wiedenmann 2014), and pesticide use malpractice (Van Hoi et al. 2009). Other major stressors causing coral decline and mass mortalities are caused by reduced salinity, shifts of dissolved inorganic nutrients (Goreau 1964, Coles 1992, Wiedenmann et al. 2013, D'Angelo and Wiedenmann 2014), and increased sea surface temperatures (Siebeck et al. 2006, Hoegh-Guldberg et al. 2007, Wooldridge 2009, Wooldridge and Done 2009) which have caused severe bleaching resulting in reduced coral reef abundance and diversity (Gardner et al. 2003, Baker et al. 
2008, Van Hooidonk et al. 2013, Ban et al. 2014, Logan et al. 2014). Corals live in a close nutritional partnership with a wide range of endosymbiotic algae (Symbiodinium) commonly referred to as zooxanthellae. When exposed to severe stress, the zooxanthellae leave their coral host, which can lead to starvation and death (Weis et al. 2008). The corals turn pale and the phenomenon is referred to as "bleaching."

Bleaching is considered an ecologically significant response variable for a number of reasons. Coral color has been found to be proportional to pigment content, e.g., chlorophyll $a$, which in turn is regulated by zooxanthellae densities (Winters et al. 2009). This relationship makes it possible to estimate degrees of stress by colorimetric methods measuring the loss of color. Moreover, proportional relationships have been found between zooxanthellae densities and coral tissue biomass (Porter et al. 1989, Szmant and Gassman 1990, Fitt et al. 1993), suggesting that coral fitness is directly related to zooxanthellae densities (however, see Cunning and Baker 2013). This notion of coral fitness is corroborated by the fact that symbiotic zooxanthellae (Symbiodinium spp.) supply the great majority ( $>95 \%)$ of coral energy demand (Muscatine and Porter 1977, reviewed in Rädecker et al. 2015) and therefore bleaching, as a sublethal stress response, is highly influenced by chlorophyll $a$ content and zooxanthellae densities (Winters et al. 2009).

Many studies have quantified the interactive effects of increased temperature and other anthropogenic stressors (e.g., marine pollution through riverine discharges) on coral bleaching (review in Ban et al. 2014). However, only a few of these have examined the combined effects of temperature and herbicides on coral bleaching (Negri and Hoogenboom 2011, Negri et al. 2011). Understanding combined effects of stressors are especially important since reef building corals in tropical and subtropical waters already exist in close proximity of their upper thermal limits (Hoegh-Guldberg et al. 2007) and are known to be sensitive to numerous pollutants (Fabricius 2005, Ban et al. 2014, D'Angelo and Wiedenmann 2014).

In this study, bleaching was measured to assess the possible additive effects of an herbicide and increased temperature on the staghorn coral Acropora formosa. A. formosa is a key reef builder, common throughout the Indo-Pacific (Veron 2000). Indicators describing photosynthetic capacity, i.e. chlorophyll $a$ content and zooxanthellae densities, were measured to quantify coral stress responses. In addition to these measurements, a new customized colorimetric method based on photography and digital image analysis in grayscale was developed to assess degrees of coral bleaching. The advantage of using of non-intrusive techniques, i.e. the presented colorimetric method, to quantify and detect early stages of coral stress is addressed and their potential use in future monitoring programs is discussed.
Glyphosate was chosen since it was found to be one of the most commonly used herbicides in rice cultures in the Nha Trang area, central Vietnam (based on interviews in nearby villages). Though glyphosate is used globally (Sirinathsinghji and Ho 2012), knowledge of its toxicological properties is scarce especially in marine organisms (Tsui and Chu 2003). Glyphosate has a high solubility in water (Solomon and Thompson 2003, Sirinathsinghji and Ho 2012), which increases its transport and bioavailability and puts aquatic organisms at risk (Sirinathsinghji and Ho 2012). Glyphosate ( $N$-[phosphonomethyl]glycine; CAS registry number 107183-6) is a post-emergence, non-selective, broad-spectrum herbicide (Solomon and Thompson 2003). Its mode of action is inhibition of an essential enzyme (5-enolpyruvyl shikimate-3$P$ synthetase) needed for the synthesis of aromatic amino acids in plants (Devine et al. 1993). Its sublethal effects are characterized by chlorosis and decreased synthesis of aromatic amino acids and of the plant hormone indolic acetic acid. These toxicity symptoms lead ultimately to death through cessation of growth and necrosis (Solomon and Thompson 2003).

Representative coral colonies were collected in Nha Trang bay (Khanh Hoa Province, South Central Vietnam), a marineprotected area since 2001, with nine islands covering approximately 16,000 ha (O'Callaghan 2008). Despite the protective measures, pollution through riverine discharges and an increase of aquaculture has had deleterious effects on key species in the bay, i.e., fish, reef building corals, and other invertebrates (O'Callaghan 2008, Thu et al. 2008). In this study, the combined effects of the herbicide glyphosate and elevated temperature were investigated on A. formosa using a new digital image method together with pigment and zooxanthellae analyses. The main novelties of the present study are (1) the study of interactive effects of temperature and herbicide in controlled laboratory experiments, (2) the development of a new digital image analysis method and its comparison to chlorophyll $a$ and zooxanthellae content, and (3) the comparison of stressor effects on two different types of zooxanthellae in A. formosa, collected from a polluted and a pristine area.

\section{Materials and methods}

\section{Experimental design and timeline}

A two-factorial experiment design was used with "temperature" (two levels: low $28{ }^{\circ} \mathrm{C}$ and high $31^{\circ} \mathrm{C}$ ) and "herbicide exposure" (five levels: 0.0, 0.12, 1.2, 6.0, and $12.0 \mathrm{mg}$ glyphosate $\mathrm{L}^{-1}$ ) as fixed factors and "coral stress responses": (1) chlorophyll $a$ content, (2) zooxanthellae densities, and (3) degree of bleaching as dependent variables. A time-line of the sampling and experiments is presented in Fig. 1. 


\section{Collection of corals and seawater}

Coral fragments of the branched staghorn coral A. formosa were collected by SCUBA diving at $2.5 \mathrm{~m}$ depth during lowest astronomical tide, NW of "Mot" Island in the vicinity of Nha Trang Bay, Vietnam $\left(12^{\circ} 10.911^{\prime} \mathrm{N}, 109^{\circ} 16.330^{\prime} \mathrm{E}\right.$; Fig. 2) on November 2 and 9, 2012. Coral branches were cut using a stainless steel plier and placed directly under water in $50 \mathrm{~mL}$ Sarstedt Falcon tubes (one fragment per tube), filled with seawater from the sampling site. Coral branches were kept individually to prevent possible chemical stress signals between fragments. The Falcon tubes were transported to the lab (ca $30 \mathrm{~min}$ ) in a water-filled cooler (kept at ambient sea temperature). Seawater in the tubes was also replaced every $15 \mathrm{~min}$ to supply coral fragments with oxygenated sampling-site water and decrease stress and defense mechanisms (e.g. production of mucus). In addition, about $120 \mathrm{~L}$ of seawater was collected from the sampling site for each experiment and transported using $20 \mathrm{~L}$ plastic carboys to the lab. Collected seawater was kept dark to minimize photosynthetic activity and stored at ambient in situ temperature $\left(28{ }^{\circ} \mathrm{C}\right)$ until the start of the experiments. In total, 70 coral branches of the same colony (80-90 mm terminal length) were collected, for experiments 1 and 2 ( $n=27$ per experiment) hereafter referred to as "Exp. 1" and "Exp. 2." Additional fragments $\left(n=8 \cdot \operatorname{Exp}^{-1}\right)$ were collected for initial controls $\left(\mathrm{T}_{0}\right.$ control), i.e. to observe initial conditions of the coral just after sampling $(n=4)$ and after the acclimatization phase in the laboratory before the start of the experiments $(n=4)$.

At the start of this study, a pilot experiment was conducted using coral branches sampled from a more pristine site located near "Mon" Island, $3 \mathrm{~km}$ SE of our current sampling site ("Mot" Island, see Fig. 2). However, the coral branches from Mon Island ( $n=70$ in total) were severely stressed after $72 \mathrm{~h}$ of acclimatization and were completely or partially bleached already at start of the exposures and could not be included in the exposure experiment, although their zooxanthellae composition was assessed as will be discussed later.

\section{Experimental setup and acclimatization phase}

Seawater used for each experiment was filtered through $1.2 \mu \mathrm{m}$ glass fiber filters (Advantec GB-100R) to eliminate "larger" planktonic species possibly biasing exposure results. Small coral stands were made to hold up each coral branch during the experiments (Fig. 3a, b). The coral stands consisted of a base made of concrete (50 $\mathrm{mm}$ diameter, $25 \mathrm{~mm}$ height) in which a cut-off $(70 \mathrm{~mm})$ plastic chopstick was inserted before the cement had hardened. The coral branches were then tied in a vertical position to the chopsticks using plastic transparent zip ties (one branch per stand). Each mounted coral branch was then placed in an acid-rinsed $\left(10 \% \mathrm{HNO}_{3}\right) 1$ L beaker filled with $700-800 \mathrm{~mL}$ of filtered sea water (FSW). The beakers were randomly placed in a temperature-controlled water bath (a large custom-made aquarium L88 $\times \mathrm{W} 65 \times \mathrm{H} 22 \mathrm{~cm}$ ) to ensure a constant temperature of each replicate beaker during the experiments (Fig. 3c). Two water baths were used, one for the $28{ }^{\circ} \mathrm{C}$ treatment and one for the $31{ }^{\circ} \mathrm{C}$ treatment (see below). Air pumps were used to circulate the water of the water bath in order to keep its temperature homogenous. A diurnal 12:12 h light cycle was maintained using $30 \mathrm{~W}$ of aquaria lamps with continuous light regulated with timers. Light and temperature were monitored continuously during the experiments, every $10 \mathrm{~min}$, using data loggers (Onset HOBO) to detect possible light and temperature deviations. Constant aeration to each beaker was provided using air pumps connected to Pasteur pipettes (one per beaker). Prior to the exposure period, coral fragments were acclimatized to laboratory conditions for 5 days, during which they were fed once with 100-250 individuals $\cdot \mathrm{mL}^{-1}$ of newly hatched crustaceans (Artemia sp.) on day 3.

\section{Herbicide treatment}

Coral fragments were exposed to the herbicide glyphosate $\left(\mathrm{C}_{3} \mathrm{H}_{8} \mathrm{NO}_{5} \mathrm{P}\right.$; CAS number 1071-83-6) purchased in Nha Trang under the common trade name "Clowdup 480SC."
Fig. 1 Experimental time-line in days. From day 1 (Nov. 2, 2012) to day 18 (Nov. 20, 2012). Exp. 1: Experiment 1 conducted at $28^{\circ} \mathrm{C}$. Exp. 2: Experiment 2 conducted at $31{ }^{\circ} \mathrm{C}$

\begin{tabular}{lll} 
a Day 1 & b Day 1-5 & C Day 6 \\
\hline Sampling of corals $\left(28^{\circ} \mathrm{C}\right)$ & Acclimation phase of Exp.1 & Start of Exp.1 \\
d Day 7 & e Day 7-12 & f Day 11 \\
\hline Sampling of corals $\left(31^{\circ} \mathrm{C}\right)$ & Acclimation phase of Exp.2 & End Exp.1
\end{tabular}

\begin{tabular}{ll} 
g Day 13 & h Day 18 \\
\hline Start of Exp.2 & End of Exp.2
\end{tabular}


a

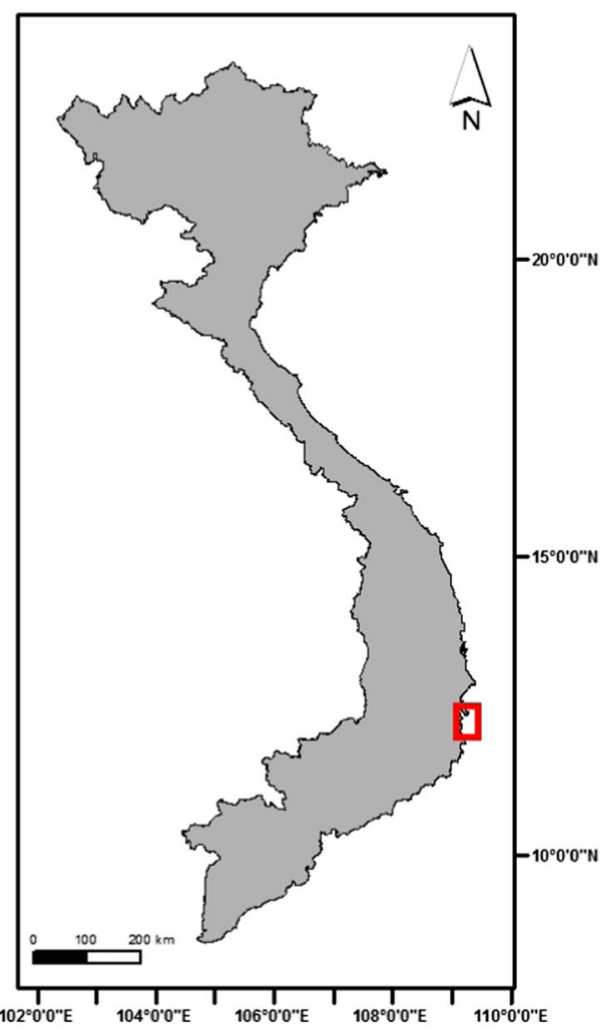

b

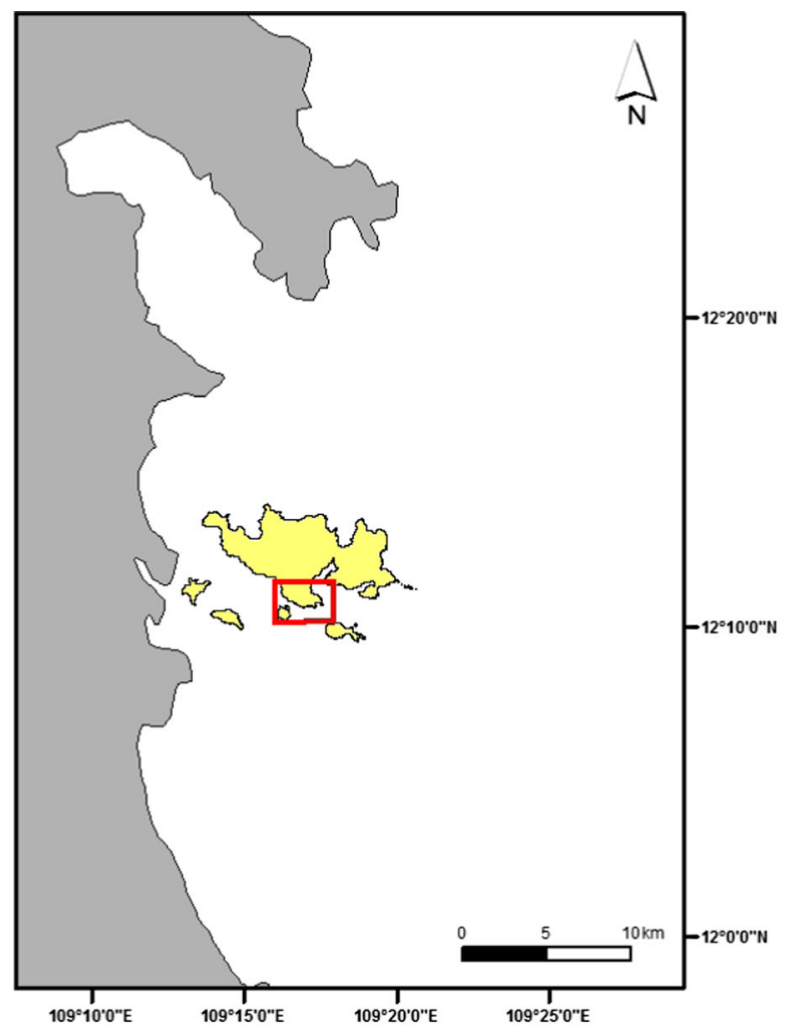

C

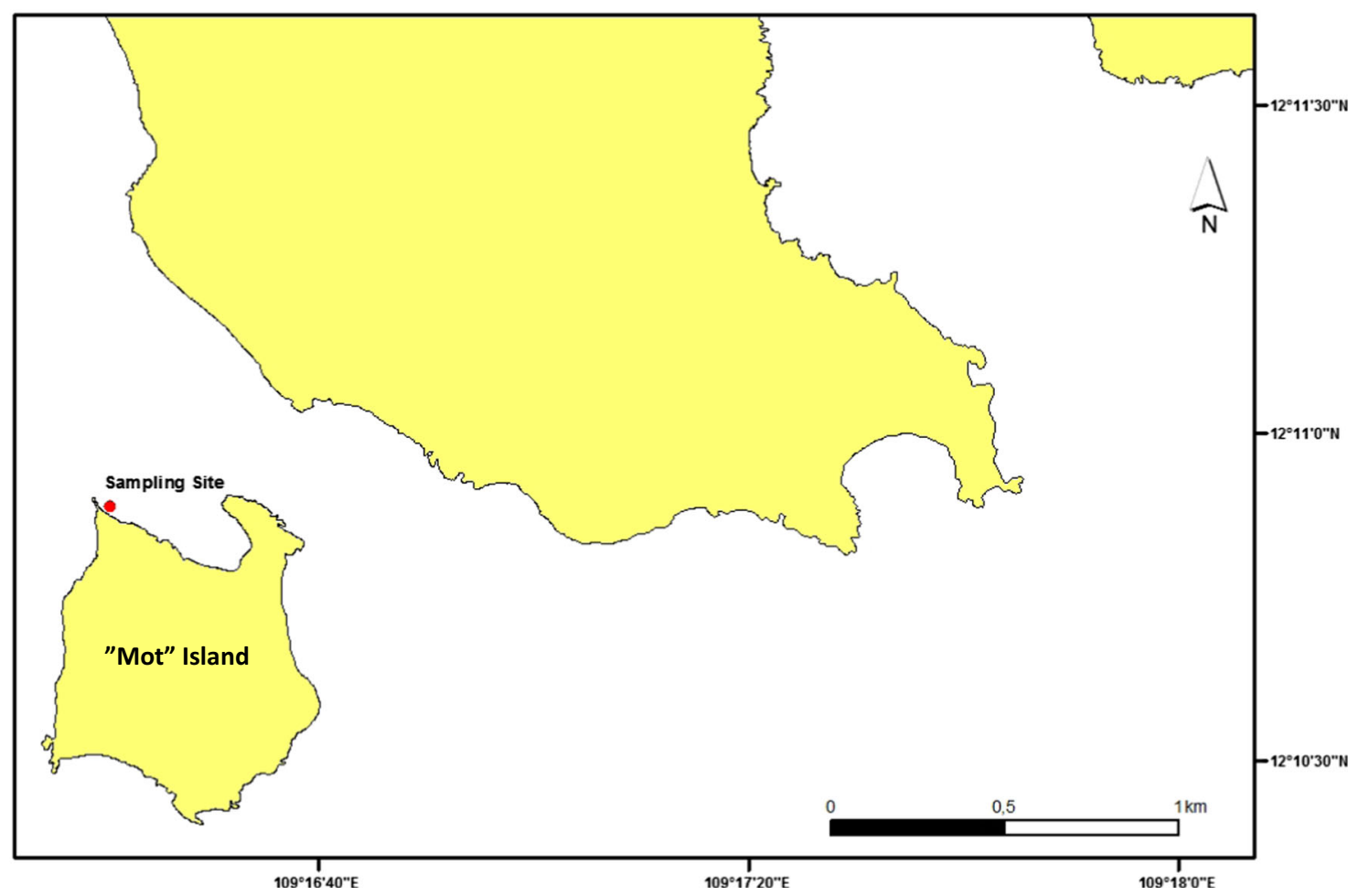

Fig. 2 Vietnam is outlined and the city of Nha Trang (red box) indicated (a). The bay of Nha Trang, showing research area (red box) in more detail (b). The sampling site from where coral fragments, that were subjected to treatments, were collected (c) 
a

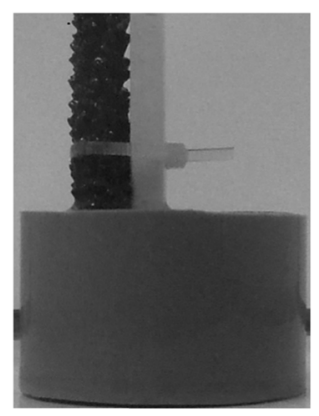

C

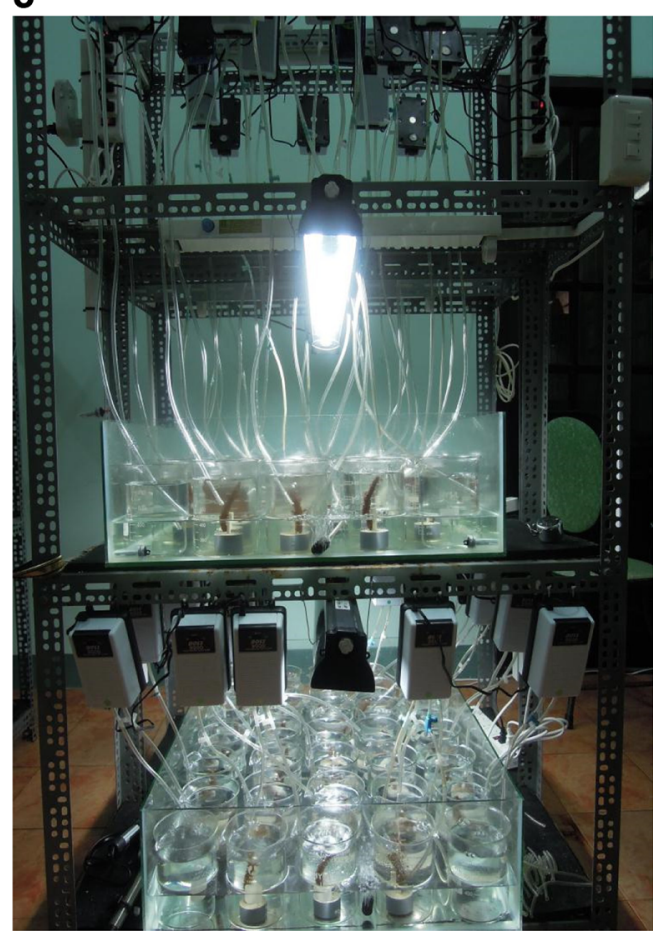

Fig. 3 Experimental setup. Custom-made coral stand with a coral fragment before (a) and after exposure (b). Picture of experimental design (c)

The experiments were carried out at the Institute of Oceanography (IO), Nha Trang between November 8 and 13, 2012 (Exp. 1) and November 15 and 20, 2012 (Exp. 2) for an exposure period of approximately 5 days $(110 \mathrm{~h})$. Nominal exposure concentrations were 0.0, 0.12, $1.2,6.0$, and $12.0 \mathrm{mg} \cdot \mathrm{L}^{-1}$ of glyphosate in the formulation, prepared from a stock solution of $120 \mathrm{mg} \mathrm{L}^{-1}$ (Exp. 1; prepared 21 Oct. 2012) and from a stock solution of $480 \mathrm{mg} \mathrm{L}^{-1}$ (Exp. 2; prepared 15 Nov. 2012). The experimental concentrations were obtained through a dilution series with experimental FSW. All concentrations in the paper are expressed as nominal concentrations of the commercial formulation. A subsample of the stock solution was brought to Sweden for confirmatory analysis and was analyzed at the Swedish University of Agricultural Science (SLU) using HPLC/tandem MS according to Hanke et al. (2008) and Jansson and Kreuger
(2010) (method OMK 59). The confirmatory analysis showed that the actual concentration of the stock solution was $108 \mathrm{mg} \mathrm{L}^{-1}$. Thus, for actual concentrations, the nominal concentrations presented in this study should be multiplied by a factor of 0.9 .

\section{Temperature treatment}

Two experiments were carried out in series at different temperature. Exp. 1 was conducted at ambient sea temperature $\left(28^{\circ} \mathrm{C}\right)$ with five replicate beakers per glyphosate exposure and 7 replicates for the negative controls (i.e. no glyphosate added). Experiment 1 and experiment 2 were identical with the exception that they were conducted in 28 and $31^{\circ} \mathrm{C}$, respectively. The $3{ }^{\circ} \mathrm{C}$ difference between the experiments was chosen to correspond to a global warming temperature increase between a low $\mathrm{CO}_{2}$ emission scenario $\left(+1.8^{\circ} \mathrm{C}\right)$ and a high $\mathrm{CO}_{2}$ emission scenario $\left(+2.4\right.$ to $\left.6.4{ }^{\circ} \mathrm{C}\right)$ proposed by the Intergovernmental Panel on Climate Change (referred to in Hoegh-Guldberg et al. 2007). The temperature treatments were conducted in two successive experiments due to logistical constraints. In each experiment, the water temperature was obtained using two aquaria heaters placed in the water bath. Potential temperature gradients were avoided by continuously circulating the water baths with air pumps.

\section{Measured endpoints}

Temperature and light conditions were continuously measured during the experiments using light and temperature loggers (UA-002-08 Onset, HOBO). Salinity (in PSU) was measured pre- and post-exposure to monitor possible deviations due to evaporation. Salinity was measured using a multimeter (WTW Multi 340i). The genotypes of zooxanthellae clades were confirmed post-exposure using Sanger sequencing of the ITS2rDNA region (see below). The following response endpoints to glyphosate and temperature treatments were determined: (1) bleaching degree (loss of color) of the corals measured by digital image analysis, (2) chlorophyll $a$ content, and (3) number and cell division frequency of the zooxanthellae.

\section{Analysis of bleaching degree using digital image analysis}

A new digital image analysis method was developed in this study for the quantification of bleaching degree. Pictures of each coral branch were taken in the laboratory before and after exposure (November 8 and November 13, Exp. 1; November 15 and November 20, Exp. 2) with a Nikon COOLPIX P300 digital camera (high resolution 24-bit JPEGs). Each coral branch was removed from its beaker and photographed in air in the laboratory. Laboratory windows were covered with black plastic 
bags and fluorescent ceiling lights were used as exposure light in order to reduce effects of different light conditions according to Thieberger et al. (1995) and Edmunds et al. (2003). Coral fragments attached to their stands were placed in a small photo-studio, i.e., in front of a white background consisting of four laminated perpendicular A4 sheets. Distance between camera and fragments was constant. Camera settings were set to auto. Corals were centered on a crosshair mark on the bottom sheet. Four perpendicular views were photographed of each coral branch, i.e. four images per coral replicate were photographed in order to get a good representation of the bleaching degree.

Pictures were analyzed digitally using ImageJ (version 1.46r). Pictures were converted from 24-bit color to 8-bit grayscale (pixel range 0-255) in order to reduce variability associated with auto-settings, i.e. lens focal length (distance to focus), aperture speed (light shutter speed), and aperture size (size of shutter opening). Two of the four opposite views (second and fourth) were analyzed for each coral fragment before and after exposure (Fig. 4a). All images were calibrated to a measuring scale (Fig. 4b). A circle was superimposed on each coral branch picture just above the bundle ties (Fig. 4c), and only pixel values within the circle were analyzed. The circle area was approximately $123 \mathrm{~mm}^{2}$. The same circle area corresponded to the coral surface area that was extracted for chlorophyll $a$ and zooxanthellae measurements (see below). The arithmetic mean of pixel values (range 0-255) in each circle was calculated (Fig. 4d) and used to obtain a combined mean value of the second and fourth perpendicular view. This value was called mean intensity of gray (MIG). One MIG value per replicate before and after exposure was compared using the following function:

$\mathrm{MIG}_{\mathrm{RE}}=1-\left(\mathrm{MIG}_{\mathrm{S}} / \mathrm{MIG}_{\mathrm{E}}\right)$.

where $\mathrm{MIG}_{\mathrm{RE}}$ is the relative mean intensity of gray; $\mathrm{MIG}_{\mathrm{S}}$ is the mean intensity of gray at start, i.e. before exposure; and $\mathrm{MIG}_{\mathrm{E}}$ is the mean intensity of gray at the end, i.e., after exposure.
Fig. 4 Image analysis of bleaching degree. Two opposite and perpendicular views of the same coral branch before (upper images) and after (lower images) exposure (a). Images were calibrated and integrated to a measuring scale to express areal coverage in $\mathrm{mm}^{2}$ (b). Circles (white dashed line) of approximately $123 \mathrm{~mm}^{2}$ were super imposed above bundle ties to quantify the bleaching intensity within the circle in two perpendicular views per coral fragment before and after exposure (c). Mean intensity of gray within circles (range 0-255) is calculated in one of the perpendicular views before (1) and after (2) exposure (d). Note the significant change in mean intensity of gray before and after exposure, i.e. bleaching severity is correlated to higher pixel values. A value of 255 is equivalent to $100 \%$ saturation (proportion of gray) or brightness (lightness and darkness)

\section{a}
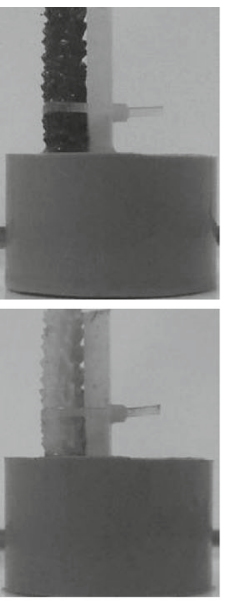

c
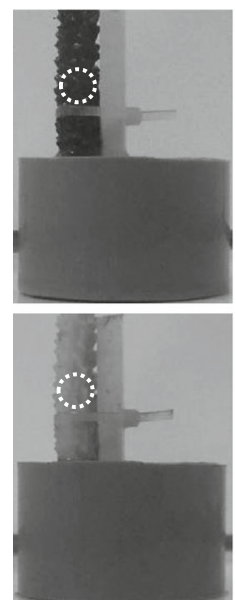

b
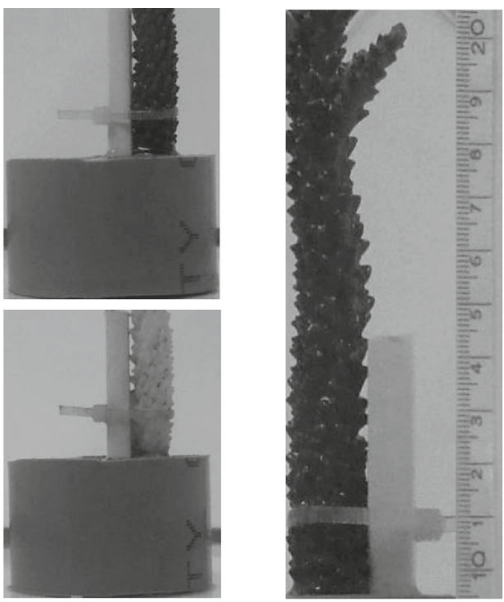

d

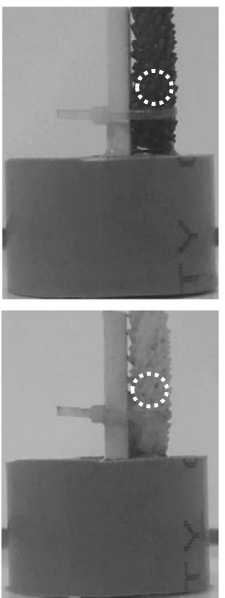

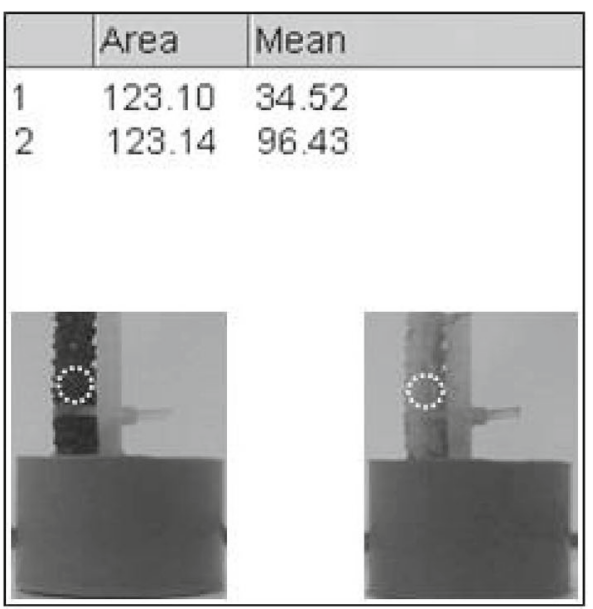




\section{Chlorophyll $\boldsymbol{a}$ and zooxanthellae}

Coral tissue samples were collected post-exposure from each replicate. Surface samples were consistently taken from the fourth perpendicular view (see above). Coral tissues were taken from a circle area of $123 \mathrm{~mm}^{2}$, corresponding to the circle used for the photometric measurements described above. A plastic lid of the right dimension $\left(123 \mathrm{~mm}^{2}\right)$ was held over the coral, above the bundle, and the coral tissue inside the circle was blasted off with $10 \mathrm{~mL}$ of FSW using $5 \mathrm{~mL}$ disposable syringes. The tissue homogenate was collected in Sarstedt Falcon tubes, and the procedure was repeated until all tissue within the circle was collected and only the coral skeleton was left. The collected tissue samples were allowed to settle in order to separate tissue from excreted mucus, which was floating on top. Thereafter, $2 \mathrm{~mL}$ aliquots were pipetted into $2 \mathrm{~mL}$ microtubes (Sarstedt). A 0.5 $\mathrm{mL}$ subsample was taken from each microtube for chlorophyll $a$ analyses, and the rest was kept for zooxanthellae measurements. The $0.5 \mathrm{~mL}$ samples were filtered (Glass fiber Advantec GB-100R). The filtrate was discarded and the filters were placed in sterile Sarstedt microtubes and stored dark at $-20{ }^{\circ} \mathrm{C}$ until extraction. Chlorophyll $a$ was extracted in $90 \%$ acetone and measured on a fluorometer (Turner 10AU ${ }^{\mathrm{TM}}$ ) according to Welschmeyer (1994) and Suggett et al. (2010) without acid treatment.

The remaining $1.5 \mathrm{~mL}$ tissue samples were used for zooxanthellae analyses and were immediately preserved in 50\% solution of glutaraldehyde. Two aliquots per replicate were stained with acidic Lugol solution, and the total number of zooxanthellae was microscopically ( $\times 400$ magnification) determined using a Bürker counting chamber (10 replicates per count). All counts were done using blind analysis to avoid bias. Cells under division (i.e., cells undergoing mitosis) were counted as two cells in the total cell count. The number of mitotic cells was also recorded separately and was named mitotic index (MI). Chlorophyll $a$ content was expressed as $\mu \mathrm{g} \cdot \mathrm{mm}^{-2}$, zooxanthellae and MI-cell counts were expressed as number. $\mathrm{mm}^{-2}$.

\section{Genotype determination of zooxanthellae clade}

Tissue samples were collected from control fragments from Mot Island $\left(n=4 \cdot \operatorname{Exp}^{-1}\right)$ and from Mon Island $(n=7)$ and stored in $70 \%$ ethanol for genetic identification of the Symbiodinium. The methods followed Hellström (2011). Shortly, the ITS2rDNA region was amplified using the primers in LaJeunesse and Trench (2000) and a modified PCR protocol based on LaJeunesse and Trench (2000) and Porto et al. (2008).
This region gives a resolution on three different taxonomic levels: clade, type, and subtype (Howells et al. 2016) differentiating subtypes with different resilience traits. The amplicons were directly sequenced and identified by BLAST search tools prior to alignment with published reference material in NCBI GeneBank.

\section{Statistical analysis}

Treatment effects (temperature and glyphosate exposure) on six dependent variables (chlorophyll $a$, zooxanthellae counts, MI counts, $\mathrm{MIG}_{\mathrm{E}}, \mathrm{MIG}_{\mathrm{RE}}$, and salinity) were tested statistically using $\mathrm{R}$ (version 2.13.2). Variables were $\ln$-transformed when necessary to fulfill assumptions of homoscedasticity and normality. Parametric assumptions were tested post analysis on standardized residuals. Each experiment consisted of 27 coral fragments, i.e. $n=7$ for controls and $n=5$ for each glyphosate concentration tested $(0.12,1.2,6.0,12.0 \mathrm{mg}$ glyphosate $\cdot \mathrm{L}^{-1}$ ).

Three separate analyses were conducted. First, the effect of herbicide exposure (five levels) and temperature (two levels) was evaluated using analysis of variance to compare any significant differences between combinations of treatment exposure (herbicide and/or temperature exposure) with experimental controls. Second, multiple linear regressions were conducted to examine possible regressions between chlorophyll $a$ (dependent variable) and predictors, i.e. zooxanthellae counts, MI counts, $\mathrm{MIG}_{\mathrm{E}}, \mathrm{MIG}_{\mathrm{RE}}$, salinity, temperature, and glyphosate exposure. The Akaike information criteria (AIC) were used to find best regression models. Third, Pearson correlations and simple linear regressions were conducted to compare the relation between chlorophyll $a$ and zooxanthellae found in this study to other colorimetrical and pigment relations reported in previous published studies. $\alpha$ was set at 0.05 in all tests.

\section{Results}

\section{Light, temperature, and salinity measurements}

Light was rather constant according to logger data, except for the variations between day and night set to a diurnal $12: 12 \mathrm{~h}$ light cycle. Water temperature was $\bar{x}=28.4{ }^{\circ} \mathrm{C}$ in Exp. 1 $\left(n=3365 ; \mathrm{SD}=0.4{ }^{\circ} \mathrm{C}\right)$ and $\bar{x}=31.2{ }^{\circ} \mathrm{C}$ in Exp. 2 $\left(n=3365 ; \mathrm{SD}=0.3^{\circ} \mathrm{C}\right)$. There were no significant differences between salinity pre- and post-exposure. The salinity was slightly higher in Exp. 2 (34.5 PSU) than in Exp. 1 (32.6 PSU) due to a higher evaporation with the $3{ }^{\circ} \mathrm{C}$ increase in temperature; see Table 1. 
Table 1 Salinity measured post exposure

\begin{tabular}{lllll}
\hline Exposure & Exp. & $\mathrm{n}$ & PSU $(\bar{x})$ & SD (in PSU) \\
\hline Control & 1 & 7 & 33.6 & 0.28 \\
G_0.12 & 1 & 5 & 33.6 & 0.22 \\
G_1.2 & 1 & 5 & 33.4 & 0.16 \\
G_6.0 & 1 & 5 & 31.9 & 0.12 \\
G_12.0 & 1 & 5 & 30.5 & 0.37 \\
Control & 2 & 7 & 35.0 & 0.68 \\
G_0.12 & 2 & 5 & 35.1 & 0.41 \\
G_1.2 & 2 & 5 & 34.6 & 0.54 \\
G_6.0 & 2 & 5 & 34.1 & 0.80 \\
G_12.0 & 2 & 5 & 34.0 & 0.48 \\
\hline
\end{tabular}

Exposure describes tested glyphosate concentrations in $\mathrm{mg} \mathrm{L}^{-1}$ with the exception of experimental controls. Exp. describes different temperature treatments where 1 is $+28^{\circ} \mathrm{C}$ and 2 is $+31^{\circ} \mathrm{C}$. $n$ is the number of replicates used. PSU values show mean and SD for each exposure group

\section{Digital image analysis}

There was no significant treatment effect on coral pigmentation by temperature or glyphosate exposure alone. However, the interaction between temperature and glyphosate exposure was significantly different from the controls for the highest concentration of herbicide $\left(12.0 \mathrm{mg} \mathrm{L}^{-1}\right)$ at the increased temperature treatment for both $\mathrm{MIG}_{\mathrm{E}}$ and $\mathrm{MIG}_{\mathrm{RE}}$ (two-way ANOVA followed by Tukey HSD post hoc test, $\mathrm{F}_{9,44}=8.5, P<0.01$ and $\mathrm{F}_{9,44}=3.1, P<0.01$ respectively; Fig. 5b, c).

\section{Chlorophyll $a$ and zooxanthellae measurements}

Similar results were observed for the chlorophyll $a$ variable, where significant interaction effects of temperature and glyphosate exposure were found for the highest herbicide concentration at the elevated temperature treatment (two-way ANOVA followed by Tukey HSD post hoc test, $\mathrm{F}_{9,44}=3.1$, $P<0.001$; Fig. 5a). No significant effects were observed for zooxanthellae or MI counts, independent of treatment combinations.

\section{Determination of the most influential predictor(s) of chlorophyll a}

Multiple regression analyses were conducted according to the following model setup:

1. Chlorophyll a Zooxanthellae counts + MI counts + $\mathrm{MIG}_{\mathrm{E}}+$ salinity + temperature + exposure

2. Chlorophyll a Zooxanthellae counts + MI counts + $\mathrm{MIG}_{\mathrm{RE}}+$ salinity + temperature + exposure
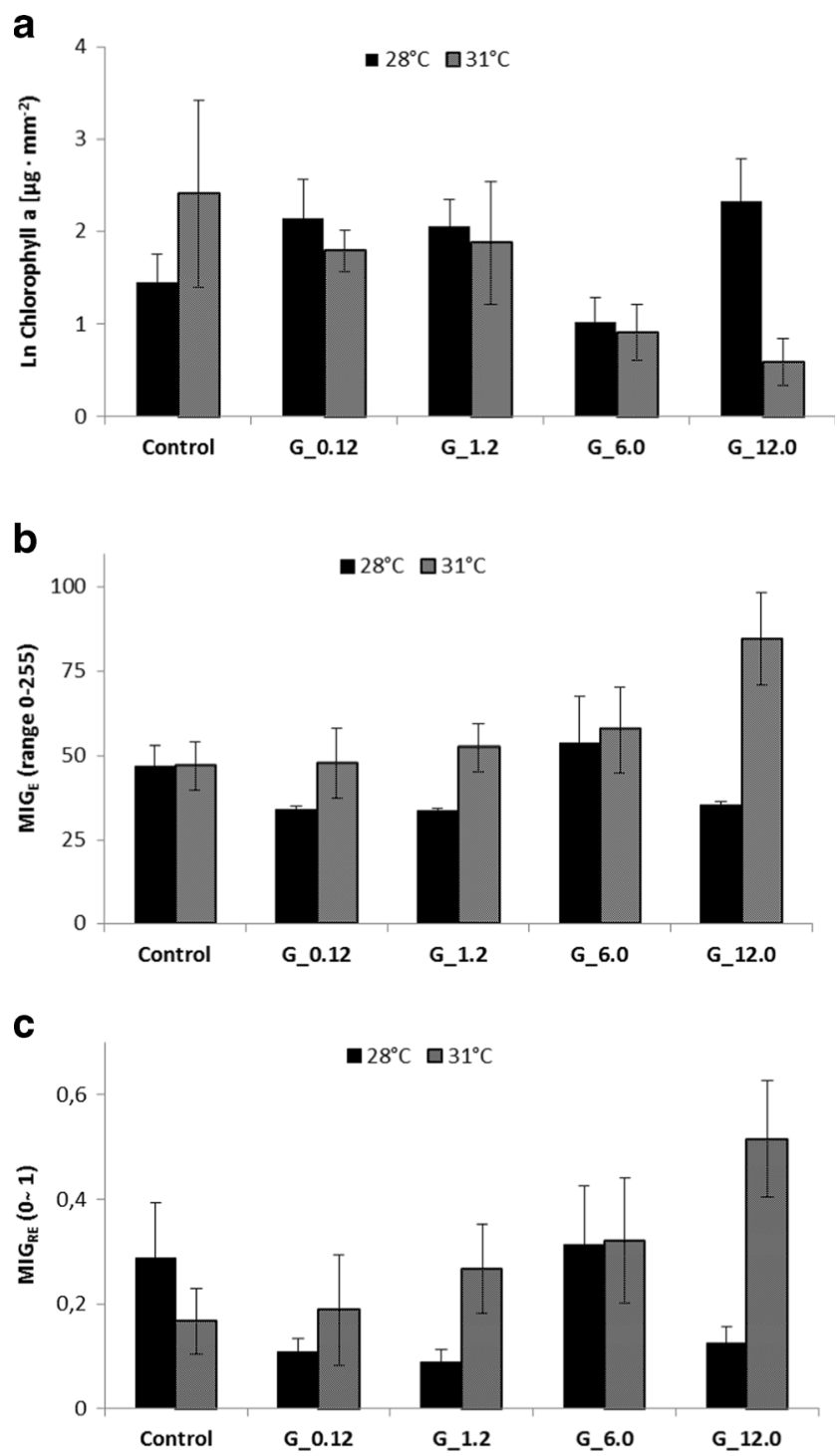

Fig. 5 Effects of herbicide exposure at +28 and $31{ }^{\circ} \mathrm{C}$ on $\ln$-transformed chlorophyll $a$ content (a), for the photometrical variable $\mathrm{MIG}_{\mathrm{E}}(\mathbf{b})$ and for the photometrical variable $\mathrm{MIG}_{\mathrm{RE}}(\mathbf{c})$. The highest herbicide concentration $\left(\mathrm{G}_{1} 12.0\right)$ at the elevated temperature exposure $\left(31^{\circ} \mathrm{C}\right)$ differs significantly from controls for all three measured variables. No other combination of treatments differs significantly from experimental controls. Error bars are SE. In Fig. $4 \mathbf{b}$, c, values are proportional to bleaching degree

In both cases, variations in chlorophyll $a$ content were best described by zooxanthellae counts and the photometric variables $\left(\mathrm{F}_{2,51}=53.8, P<0.001\right.$ zooxanthellae counts and $\mathrm{MIG}_{\mathrm{E}}$ respectively, $r^{2}=0.68$ and $\mathrm{F}_{2,51}=49.3, P<0.001$ zooxanthellae counts and $\mathrm{MIG}_{\mathrm{RE}}$ respectively, $r^{2}=0.66$ ). Results of the multiple regression models 1 and 2 are presented in Fig. 6a, b.

The number of zooxanthellae correlated significantly with the photometric variables (Pearson correlations; $P<0.001 \mathrm{MIG}_{\mathrm{E}}$, $r=-0.58$ and $P<0.001 \mathrm{MIG}_{\mathrm{RE}}, r=-0.57$; Fig. $7 \mathrm{a}$, b respectively). Simple linear regressions revealed significant relationships between chlorophyll $a$ and photometric variables $\left(\mathrm{MIG}_{\mathrm{E}}\right.$, 

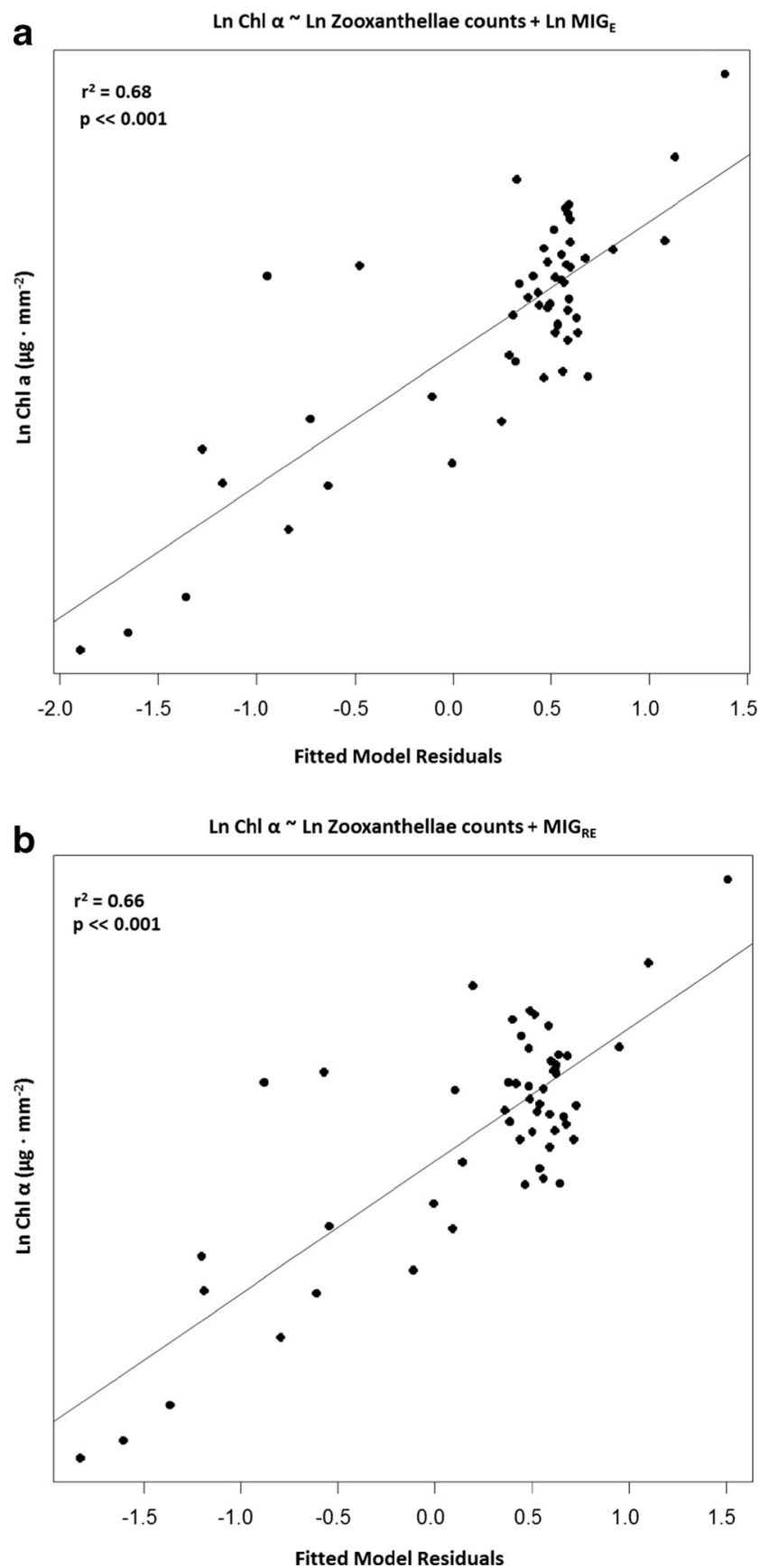

Fig. 6 Plots from multiple regression analyses where the residuals for the best model, highly influenced by zooxanthellae densities and photometric variables, are plotted against chlorophyll $a$. Initial model inputs were identical with the exception of photometric variables, $\mathrm{MIG}_{\mathrm{E}}$ in (a) and $\mathrm{MIG}_{\mathrm{RE}}$ in (b)

$\mathrm{F}_{1,52}=56.9, P<0.001, r^{2}=0.52$ and $\mathrm{MIG}_{\mathrm{RE}}, \mathrm{F}_{1,52}=48.2$, $P<0.001, r^{2}=0.48$; Fig. 7c, d respectively).

\section{Genotype analysis}

The Symbiodinium types in all fragments from Mot Island were identified as C3u (NCBI accession number GU111879) and from Mon Island as C21 and C23 (NCBI accession number AY239372 and EU499102)

\section{Discussion}

Branches of the staghorn coral A. formosa were not significantly bleached by temperature increase $\left(3^{\circ} \mathrm{C}\right)$ or by herbicide exposure alone. However, the combination of these two stressors, i.e. both elevated water temperature and herbicide exposure, caused a significant decrease of chlorophyll $a$ (Fig. 5a) and a significant color loss (Fig. 5b, c). The similar responses of the photometric variables and the chlorophyll $a$ suggest that coral bleaching is related to the concentration of photopigments and moreover quantifiable by digital photometry methods. This is further supported by the significant regressions found between chlorophyll $a$ and the two photovariables $\mathrm{MIG}_{\mathrm{E}}$ and $\mathrm{MIG}_{\mathrm{RE}}$ (Fig. 7c, d).

Various environmental stressors, such as contaminants (Ban et al. 2014) and increased sea surface temperatures (Coles and Jokiel 1977, Brown 1997, Hoegh-Guldberg 1999, Van Hooidonk et al. 2013, Logan et al. 2014), can cause coral bleaching. Results from the present survey is in line with previous studies which highlight the importance of synergistic effect caused by rising temperatures in combination with pollutants (reviewed in Ban et al. 2014).

Predictive scenarios regarding elevated temperature and subsequently increased stress on coral communities are particularly important for reef building corals in tropical and subtropical waters. Coral reefs worldwide are already experiencing their thermal tolerance limits (HoeghGuldberg et al. 2007) and in many areas, including Vietnam, exposed to heavy pollution, including pesticide malpractice use (Van Hoi et al. 2009), through riverine discharges. On the other hand, predictive models of coral bleaching need to consider adaptive responses in the coral host (Palumbi et al. 2014) and stress tolerance differences in the symbiotic algae (Coles et al. 1976, Berkelmans 2002, Riegl et al. 2011).

The critical temperatures for activating coral bleaching differ considerably between geographic regions indicating that corals and their symbionts undergo adaptation to their environments (e.g. Coles et al. 1976, Berkelmans 2002, Riegl et al. 2011). Corals showing altered bleaching patterns may adapt to warming over time (Guest et al. 2012, Maynard et al. 2008, Pratchett et al. 2013). Resilient corals of the same species seem to acclimatize to increasing temperatures by hosting stress-tolerant zooxanthellae types (Hume et al. 2015, Silverstein et al. 2015, Howells et al. 2016) combined with adaptation of the coral itself (Barshis et al. 2013, Palumbi et al. 2014). These adaptations include regulations of an array of thermal response genes, including heat shock proteins and antioxidant enzymes (Barshis 
a

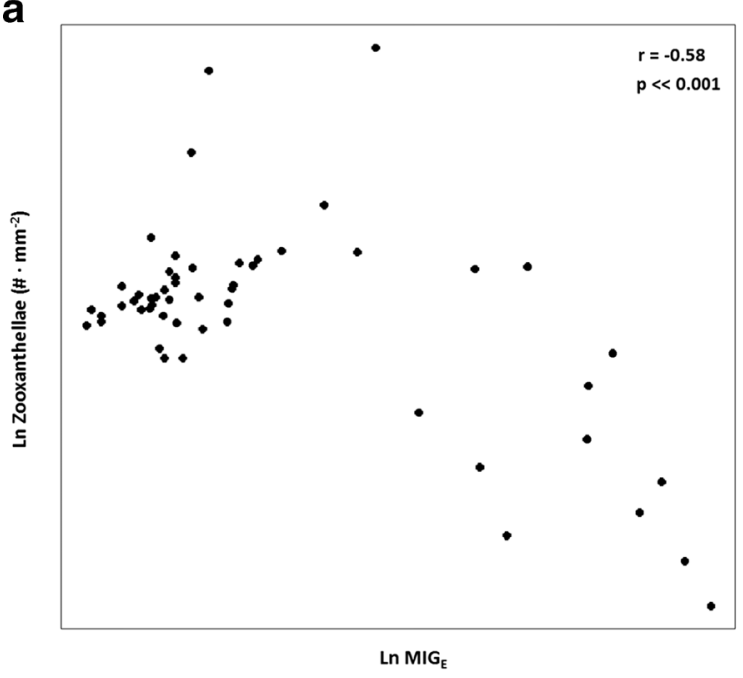

C

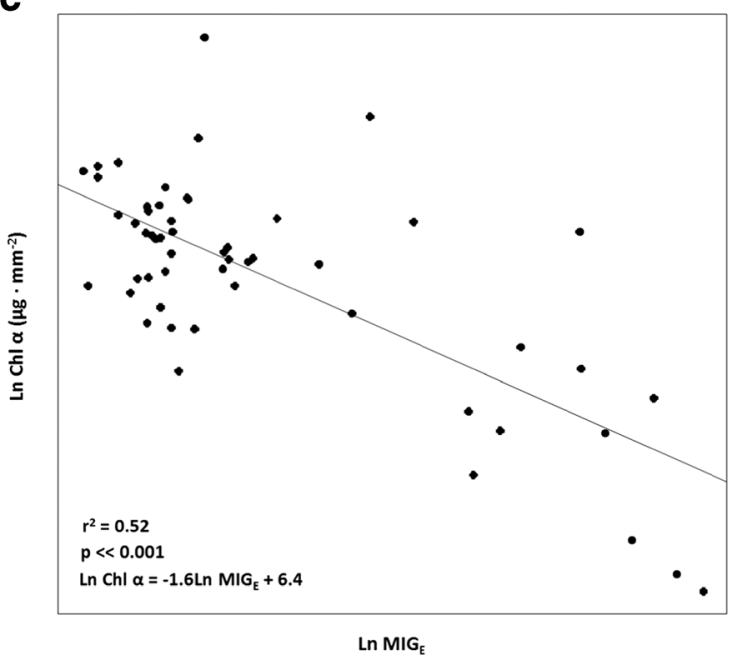

Fig. 7 Significant correlations and regressions between the number of zooxanthellae or chlorophyll $a$ content and photometric variables in both experiments, total $n=54$ (a, b and $\mathbf{c}, \mathbf{d}$, respectively). Note the negative

et al. 2013). However, multiple stressors may slow down this acclimatization mechanism causing more permanent damage to corals (Carilli et al. 2009).

These cellular mechanisms may explain why zooxanthellae densities in the Nha Trang bay corals, collected in the vicinity of Mot Island, did not differ significantly between temperature exposures. The endosymbiotic zooxanthellae clade in all these fragments was identified as $\mathrm{C} 3 \mathrm{u}$. In Vietnam, the clade $\mathrm{C} 3 \mathrm{u}$ is found in areas with high chlorophyll $a$ contents or close to human populations or fish farms with high nitrogen effluent (Hellström, 2011). The clades from the MPA corals in this study were identified as C21 and C23, which have been connected to more pristine sites. These results, i.e. that coral fragments from Mot Island endured the full length of the experimental period while bleaching rates were high during the acclimatization phase for coral branches sampled from
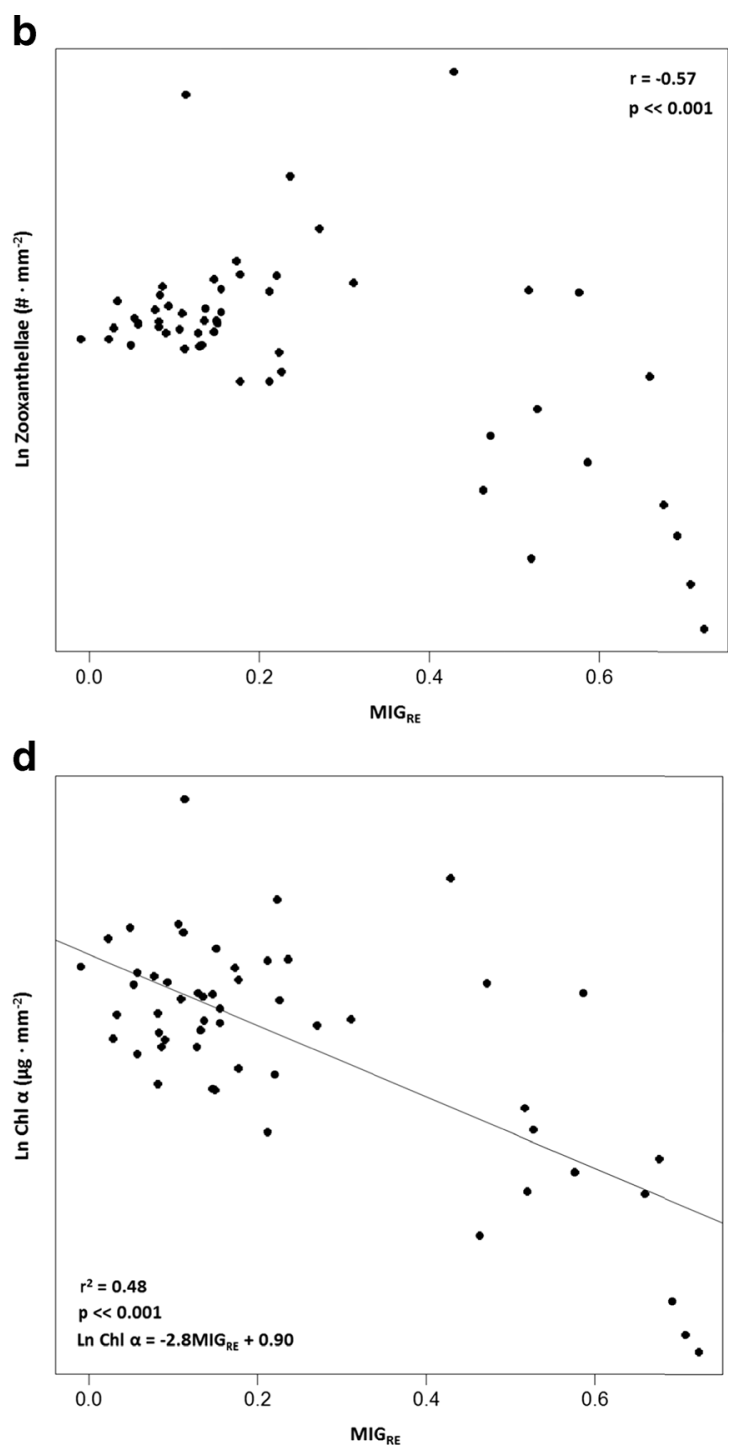

relationship describing decline in the number of zooxanthellae or chlorophyll $a$ content with increasing $\mathrm{MIG}_{\mathrm{E}}$ or $\mathrm{MIG}_{\mathrm{RE}}$ values

Mon Island, are very interesting and indicate that the corals have different sensitivities and are able to evolve and adapt to anthropogenic stressors. More importantly, variability associated to zooxanthellae genotypes may reflect survival properties of coral species. In this study, the coral fragments collected from Mot Island were surrounded by fish farms and subjected to riverine discharges from Nha Trang. Mon Island on the other hand is isolated and less exposed to anthropogenic stress, i.e., aquaculture farms and riverine discharges. It is therefore likely that corals near Mot Island are more adapted to environmental stressors and are thus more tolerant than the ones at Mon Island. Results from this study show that the combined stress of elevated temperature and high herbicide exposure has more pronounced effects on coral bleaching than one of these stressors alone. This is in line with the study of Negri et al. (2011) where three 
herbicides (photosystem II inhibitors) with different modes of action were used simultaneously. Further studies are needed where the synergistic effects of herbicides with different modes of action is tested (Ban et al. 2014).

The essential implications of the present study, however, are described in the additive association of temperature to environmental stressors, e.g. herbicide exposure, but also in the revelation that there is a threshold even for well-adapted corals, e.g. corals with $\mathrm{C} 3 \mathrm{u}$ zooxanthellae clades, to humaninduced stress.

\section{Analysis of coral bleaching degree using digital photography}

The digital photometry method developed in this study, i.e. by determining the mean intensity of gray variables $\mathrm{MIG}_{\mathrm{E}}$ and $\mathrm{MIG}_{\mathrm{RE}}$, was successful in detecting the bleaching degree of coral fragments in response to temperature and herbicide treatments (Fig. 5b, c). The fact that $\mathrm{MIG}_{\mathrm{E}}$ and $\mathrm{MIG}_{\mathrm{RE}}$ results were very similar to those expressed in chlorophyll $a$ content and that variations in chlorophyll $a$ were best described by the photometric variables and number of zooxanthellae, i.e. multiple linear regression results for model 1 and 2, respectively (Fig. 6a, b), adds further weight to the conclusion that there is a relationship between color, chlorophyll $a$, and the number of zooxanthellae as suggested by Winters et al. (2009). This relationship is described in the provided regression equations (Fig. 7c, d) where chlorophyll concentrations can be derived from digital imagery through the photometric variables $\mathrm{MIG}_{\mathrm{E}}$ and $\mathrm{MIG}_{\mathrm{RE}}$.

Despite that the bleaching analysis was performed in grayscale (range 0-255) to exclude variations associated to camera settings, better correlation and regression results were acquired compared to earlier studies performed in color (Fig. 7a-d) but also in comparison with a recent study performed in grayscale. In this study, the number of zooxanthellae correlated significantly with the photometric variables $\left(P<0.001, \mathrm{MIG}_{\mathrm{E}}, r=-0.58\right.$ and $\left.\mathrm{MIG}_{\mathrm{RE}}, r=-0.57\right)$. In Edmunds et al. (2003) the correlation between the number of zooxanthellae and the photometric variable was $r=-0.45$ $(P<0.001)$, where color values were based on three standard bands, i.e. red, green, and blue, compared to one band in this study, i.e. grayscale. Simple linear regressions revealed significant relationships between chlorophyll $a$ and photometric variables $\left(P<0.001, \mathrm{MIG}_{\mathrm{E}}, r^{2}=0.52\right.$ and $\mathrm{MIG}_{\mathrm{RE}}$, $\left.r^{2}=0.48\right)$. In Siebeck et al. (2006), a significant relationship was found $\left(P<0.001, r^{2}=0.36\right)$ between chlorophyll $a$ and color reference card values but the resolution of the color card method was low. Also, in comparison with a recent study performed in grayscale (Chow et al. 2016, $P=0.04$, $r^{2}=0.38$ ), the photometric variables in this study rendered better results.
Our results with this new photometry method are promising; however, more work is needed to adapt the method to be used directly in the field by SCUBA diving. The advantages of taking pictures in air are excluded bias from variations in light intensity and focal distance. More approximate methods, e.g., the coral color reference card developed in Siebeck et al. (2006), were developed for field conditions and are inaccurate when higher resolutions are needed (Chow et al. 2016) and may be more useful in combination with photometric methods developed in this study. Photometric methods also reduce interobserver variability. The possibility to accurately detect coral community response to a myriad of stressors without the use of intrusive and time-consuming techniques has been the main incentive behind this relative new field of assessing physiological stress by means of color deviations.

\section{Variability associated with zooxanthellae densities}

Alternatively, the lack of significant difference between treatment replicates and experimental controls could be accredited by the large natural variation of zooxanthellae densities, influenced by spatial orientation of coral fragments relative to sunlight, attenuation of light with depth and/or water turbidity. Moreover, zooxanthellae densities might differ vertically within coral fragments. During sampling, we observed irregular coloring (i.e. brightness of color hues) in the basal part of the fragments were tissue samples were taken. This was however not the case for the uppermost part (terminal 20-30 mm), which deviated much less between fragments. Finally, the lack of significant differences in zooxanthellae between treatments may also be due to the counting method used since Lugol does not discriminate between live and dead cells, which may have led to an overestimation of zooxanthellae counts in this study. A more suitable method would have been to estimate cell counts by means of a fluorometric method such as fluorescein isothiocyanate (FITC), which differentiates between live and dead cells. The mitotic index (MI), a division frequency of zooxanthellae undergoing mitosis, has been suggested as a potential stress measurement endpoint (Brown 1988). The MI has been suggested to increase in order to counteract the expulsion of zooxanthellae by the coral host following herbicide and/or temperature exposure (Hoegh-Guldberg and Smith 1989; Fitt et al. 1993; Jones 1995). No significant treatment effects were observed on the MI in this study. This further questions the relevance of MI as a stress response variable since it can both increase and decrease in response to stress (Jones 1997).

\section{Conclusion}

Coral bleaching is important to monitor since the symbiotic zooxanthellae (Symbiodinium spp.) supply the great majority 
(>95\%) of the coral host energy demand (Hoegh-Guldberg et al. 2007). Most importantly, the proportionality of chlorophyll $a$ content to color, which in turn is highly regulated by zooxanthellae densities (Winters et al. 2009), justifies the use of colorimetric methods to assess coral physiology. The results from this study show that there is a significant correlation between chlorophyll $a$ and intensity of gray measured using digital photography analysis and that our colorimetric variables $\mathrm{MIG}_{\mathrm{E}}$ and $\mathrm{MIG}_{\mathrm{RE}}$ are good descriptors of coral bleaching and less intrusive and time consuming than chlorophyll $a$ extraction and analysis. Based on our results, we also suggest that future steps should be taken to further develop photography and digital image analysis of coral bleaching in situ as a proxy for detecting physiological changes such as loss of chlorophyll and zooxanthellae.

Acknowledgements We wish to thank the staff at the Institute of Oceanography in Nha Trang, Vietnam, in particular Dr. Bui Hong Long, Hanh Nguyen, and Dr. Doan Nhu Hai for their kind assistance; Sarah Mak for molecular laboratory work; Elena Gorokhova and Pavel Ivanov for discussions concerning image processing methods; Olle Hjerne for the statistical inputs; Selima Ben Mustapha and Jose Beltran for the image classification discussions; and Nils Hedberg, Åsa Nilsson, Isabell Stenson, and Linda Stenbäck for the field assistance.

This study was funded by Sida grant nr (54090026), the Minor Field Study scholarship fellowship program, and Stockholm University faculty funds.

Open Access This article is distributed under the terms of the Creative Commons Attribution 4.0 International License (http:// creativecommons.org/licenses/by/4.0/), which permits unrestricted use, distribution, and reproduction in any medium, provided you give appropriate credit to the original author(s) and the source, provide a link to the Creative Commons license, and indicate if changes were made.

\section{References}

Baker AC, Glynn PW, Riegl B (2008) Climate change and coral reef bleaching: an ecological assessment of long-term impacts, recovery trends and future outlook. Estuar Coast Shelf Science 80:435-471

Ban SS, Graham NAJ, Connolly SR (2014) Evidence for multiple stressor interactions and effects on coral reefs. Glob Change Biol 20:681697

Barshis DJ, Ladner JT, Oliver T, Seneca FO, Traylor-Knowles N, Palumbi SR (2013) Genomic basis for coral resilience to climate change. Proc Natl Acad Sci 110:1387-1392

Berkelmans R (2002) Time-integrated thermal bleaching thresholds of reefs and their variation on the Great Barrier Reef. Mar Ecol Prog Ser 229:73-82

Brown BE (1988) Assessing the environmental impacts on coral reefs. Proc 6th international coral reef symposium. Australia 1:71-87

Brown BE (1997) Coral bleaching: causes and consequences. Coral Reefs 16:129-138

Carilli JE, Norris RD, Black BA, Walsh SM, McField M (2009) Local stressors reduce coral resilience to bleaching. PLoS One 4(7):e6324

Cervino JM, Hayes RL, Honovich M, Goreau TJ, Jones S, Rubec PJ (2003) Changes in zooxanthellae density, morphology, and mitotic index in hermatypic corals and anemones exposed to cyanide. Mar Pollut Bull 46(5):573-586
Chow MH, Tsang RHL, Lam EKY, Ang Jr. P (2016) Quantifying the degree of coral bleaching using digital photographic technique. J Exp Mar Biol Ecol 479:60-68

Coles SL (1992) Experimental comparison of salinity tolerances of reef corals from the Arabian Gulf and Hawaii. Evidence for hypersaline adaptation. Proc 7th Int Coral Reef Symp 1:227-234

Coles SL, Jokiel PL (1977) Effects of temperature on photosynthesis and respiration in hermatypic corals. Mar Biol 43:209-216

Coles SL, Jokiel PL, Lewis CR (1976) Thermal tolerance in tropical versus subtropical Pacific reef corals. Pac Sci 30:155-166

Cunning R, Baker AC (2013) Excess algal symbionts increase the susceptibility of reef corals to bleaching. Nat Clim Chang 3(3):259-262

D'Angelo C, Wiedenmann J (2014) Impacts of nutrient enrichment on coral reefs: new perspectives and implications for coastal management and reef survival. Curr Opin Environ Sustain 7:82-93

Devine MD, Duke SO, Fedtke C (1993) Physiology of herbicide action. Ed. Englewood Cliffs, NJ: Prentice Hall, 251-294.

Edmunds PJ, Gates RD, Gleason DF (2003) The tissue composition of Montastraea franksi during a natural bleaching event in the Florida keys. Coral Reefs 22:54-62

Fabricius KE (2005) Effects of terrestrial runoff on the ecology of corals and coral reefs: review and synthesis. Mar Pollut Bull 50:125-146

Fitt WK, Spero HJ, Halas J, White MW, Porter JW (1993) Recovery of the coral Montastrea Annularis in the Florida keys after the 1987 'bleaching event'. Coral Reefs 12:57-64

Gardner T, Côté I, Gill J, Grant A, Watkinson A (2003) Long-term region-wide declines in Caribbean corals. Science 301:958-960

Goreau TF (1964) Mass expulsion of zooxanthellae from Jamaican reef communities after Hurricane Flora. Science 145:383-386

Guest JR, Baird AH, Maynard JA, Muttaqin E, Edwards AJ, Campbell SJ (2012) Contrasting patterns of coral bleaching susceptibility in 2010 suggest an adaptive response to thermal stress. PLoS ONE 7(3): e33353. doi:10.1371/journal.pone.0033353

Hanke I, Singer H, Hollender J (2008) Ultratrace-level determination of glyphosate, aminomethylphosphonic acid and glufosinate in natural waters by solid-phase extraction followed by liquid chromatography-tandem mass spectrometry: performance tuning of derivatization, enrichment and detection. Anal Bioanal Chem 391:2265-2276

Hellström M (2011) Sex and symbionts: new discoveries in coral ecology and reproduction on local and regional scales. PhD thesis, Stockholm University, Sweden, ISBN 978-91-7447-310

Hoegh-Guldberg O, Smith GJ (1989) Influence of population density of zooxanthellae and supply of ammonium ions on the biomass and metabolic characteristics of the reef corals Seriatopora hystrix and Stylophora pistillata. Mar Ecol Prog Ser 57:173-186

Hoegh-Guldberg O (1999) Climate change, coral bleaching and the future of the world's coral reefs. Mar Freshw Res 50:839-866

Hoegh-Guldberg O, Mumby PJ, Hooten AJ, Steneck RS, Greenfield P, Gomez E, Harvell CD, Sale PF, Edwards AJ, Caldeira K, Knowlton N, Eakin CM, Iglesias-Prieto R, Muthiga N, Bradbury RH, Dubi A, Hatziolos ME (2007) Coral reefs under rapid climate change and ocean acidification. Science 318:1737-1742

Howells EJ, Abrego D, Meyer E, Kirk NL, Burt JA (2016) Host adaptation and unexpected symbiont partners enable reef-building corals to tolerate extreme temperatures. Glob Chang Biol. doi:10.1111 /gcb. 13250

Hume BCC, D'Angelo C, Smith EG, Stevens JR, Burt J, Wiedenmann J (2015) Symbiodinium thermophilum sp. nov., a thermotolerant symbiotic alga prevalent in corals of the world's hottest sea, the Persian/Arabian Gulf. Sci Rep 5(8562):1-8

Jansson C, Kreuger J (2010) Multiresidue analysis of 95 pesticides at low nanogram/liter levels in surface waters using online preconcentration and high performance liquid chromatography/ tandem mass spectrometry. J AOAC Int 93:1732-1747 
Jones RJ (1995) Sublethal stress assessment in scleractinia and the regulatory biology of the coral-algal symbiosis. $\mathrm{PhD}$ thesis, James Cook University, Townsville

Jones RJ (1997) Zooxanthellae loss as a bioassay for assessing stress in corals. Mar Ecol Prog Ser 149:163-171

LaJeunesse TC, Trench RK (2000) The biogeography of two species of Symbiodinium (Freudenthal) inhabiting the intertidal anemone, Anthopleura elegantissima (Brandt). Biol Bull 199:126-134

Logan CA, Dunne JP, Eakin CM, Donner SD (2014) Incorporating adaptive responses into future projections of coral bleaching. Glob Chang Biol 20:125-139

Maynard JA, Anthony KRN, Marshall PA, Masiri I (2008) Major bleaching events can lead to increased thermal tolerance in corals. Mar Biol 155:172-182

Muscatine L, Porter JW (1977) Reef corals: mutualistic symbioses adapted to nutrient-poor environments. Bioscience 27:454-460

Negri AP, Hoogenboom MO (2011) Water contamination reduces the tolerance of coral larvae to thermal stress. PLoS One 6(5):e19703

Negri AP, Flores F, Röthig T, Uthicke S (2011) Herbicides increase the vulnerability of corals to rising sea surface temperature. Limnol Oceanogr 56(2):471-485

O'Callaghan B (2008) Vietnam: a collaborative approach to MPA development. The World Conservation Union, Global Coral Reef Portfolio

Palumbi SR, Barshis DJ, Traylor-Knowles N, Bay RA (2014) Mechanisms of reef coral resistance to future climate change. Science 344:895-897

Pandolfi JM et al (2003) Global trajectories of the long-term decline of coral reef ecosystems. Science 301:955-958

Porter JW, Fitt WK, Spero HJ, Rogers CS, White MW (1989) Bleaching in reef corals: physiological and stable isotopic responses. Proc Natl Acad Sci 86:9342-9346

Porto I, Granados C, Restrepo J (2008) Macroalgal-associated dinoflagellates belonging to the genus Symbiodinium in Caribbean reefs. PLoS One 3(5)

Pratchett MS, Pisapia C, Sheppard C (2013) Background mortality rates for recovering populations of Acropora cytherea in the Chagos Archipelago, central Indian Ocean. Mar Environ Res 86:29-34

Rädecker N, Pogoreutz C, Voolstra CR, Wiedenmann J, Wild C (2015) Nitrogen cycling in corals: the key to understanding holobiont functioning? Trends in Microbiology 23(8):490-497

Riegl BM, Purkis SJ, Al-Cibahy AS, Abdel-Moati MA, Hoegh-Guldberg O (2011) Present limits to heat-adaptibility in corals and populationlevel responses to climate extremes. PLos ONE 6(9):e24802. doi:10.1371/journal.pone.0024802

Siebeck UE, Marshall NJ, Kluter A, Hoegh-Guldberg O (2006) Monitoring coral bleaching using a colour reference card. Coral Reefs 25:453-460

Silverstein RN, Cunning R, Baker AC (2015) Change in algal symbiont communities after bleaching, not prior heat exposure, increases heat tolerance of reef corals. Glob Change Biol 21:236-249
Sirinathsinghji E, Ho MW (2012) Why glyphosate should Be banned. Science in Society 56:21-32

Solomon K, Thompson D (2003) Ecological risk assessment for aquatic organisms from over-water uses of glyphosate. Journal of toxicology and environmental health. Part B: Critical Reviews 6(3):289-324

Suggett DJ, Prášil O, Borowitzka MA (2010) Chlorophyll a fluorescence in aquatic sciences: methods and applications. Springer, New York

Szmant AM, Gassman NJ (1990) The effects of prolonged 'bleaching' on the tissue biomass and reproduction of the reef coral Montastrea Annularis. Coral Reefs 8:217-224

Thieberger Y, Kizner Z, Achituv Y, Dubinsky Z (1995) A novel, nondestructive bioassay for assessing areal chlorophyll a in hermatypic cnidarians. Limnol Oceanogr 40:1166-1173

Thu PM, Schaepman ME, Leemans R, An NT, Son TPH, Tien NM, Bac PT (2008) Water quality assessment in the Nha Trang bay (Vietnam) by using in-situ and remotely sensed data. International Symposium on Geoinformatics for Spatial Infrastructure Development in Earth and Allied Sciences.

Tsui MTK, Chu LM (2003) Aquatic toxicity of glyphosate-based formulations: comparison between different organisms and the effects of environmental factors. Chemosphere 52:1189-1197

Van Hooidonk R, Maynard JA, Planes S (2013) Temporary refugia for coral reefs in a warming world. Nat Clim Chang 3:508-511

Van Hoi P, Mol APJ, Oosterveer P, Van den Brink PJ (2009) Pesticide distribution and use in vegetable production in the Red River Delta of Vietnam. Renewable Agriculture and Food Systems 24(3):174 185

Veron J (2000) Corals of the world. Australian Institute of Marine Science, Townsville, Australia. Vol 1:204-205

Weis VM, Davy SK, Hoegh-Guldberg O, Rodriguez-Lanetty M, Pringe JR (2008) Cell biology in model systems as the key to understanding corals. Trends Ecol Evol 23:369-376

Welschmeyer NA (1994) Fluorometric analysis of chlorophyll a in the presence of chlorophyll $\mathrm{b}$ and pheopigments. Association for the Sciences of Limnology and Oceanography 39(8):1985-1992

Wiedenmann J, D'Angelo C, Smith EG (2013) Nutrient enrichment can increase the susceptibility of reef corals to bleaching. Nat Clim Chang 3:160-164

Wilkinson C (2008) Status of coral reefs of the world: 2008, 5th global report. Australia, Global Coral Reef Monitoring Network and Reef and Rainforest Research Centre

Winters G, Holzman R, Blekhman A, Beer S, Loya Y (2009) Photographic assessment of coral chlorophyll contents: implications for ecophysiological studies and coral monitoring. J Exp Mar Biol Ecol 380:25-35

Wooldridge SA (2009) Water quality and coral bleaching thresholds: Formalising the linkage for the inshore reefs of the great barrier reef, Australia. Mar Poll Bull 58:745-751

Wooldridge SA, Done TJ (2009) Improved water quality can ameliorate effects of climate change on corals. Ecol Appl 19(6):1492-1496 